\title{
Gallic acid as the major antioxidant in pequi (Caryocar brasiliense Camb.) fruit peel
}

ROCHA, L.B.1; MELO, A.M.1*; PAULA, S.L.A.1; NOBRE, S.A.M. 1; ABREU, I.N. ${ }^{2}$

${ }_{1}^{1}$ Programa de Pós-graduação em Ciências Biológicas, Universidade Estadual de Montes Claros, Av. Dr. Rui Braga, S/N, CEP: 39.401-089, Montes Claros, MG, Brasil. ${ }^{2}$ Scottish Crop Research Institute, Natural Products and Food Quality Program, Mylnefield, Invergowrie, Dundee DD2 5DA, UK *Autor para correspondência: geraldo. melo@unimontes.br

\begin{abstract}
In this study, ethanol-water extracts of pequi fruit peel were fractionated in order to identify and quantify the major antioxidant present in it. The fractions were subjected to liquid-liquid phase extraction and silica-gel column chromatography, and antioxidant activity was monitored using the 2,2-diphenyl-1-picrylhydrazyl radical-scavenging assay. The purity of the fractions was evaluated using thin-layer chromatography and high-performance liquid chromatography (HPLC). The substance with antioxidant property was identified through the analysis in a liquid chromatography-mass spectroscopy fragmentation and was quantified using HPLC. After the Silica-gel fractionation, it was identified a fraction with high antioxidant activity and purity, which contained gallic acid as the main compound. The gallic acid was found at the amount of $26.54 \pm 1.13 \mathrm{mg} / \mathrm{g}$ of the dry mass of the pequi fruit peel. Because the quantifications were performed using crude ethanol-water extract, it was suspected that gallic acid was present in a free form. Thus, pequi fruit peel may serve as an attractive alternative of feedstock for natural antioxidant production. Moreover, the results obtained in this study emphasize the value of the pequi plant, and suggests improved opportunities for families that use this fruit's products.
\end{abstract}

Keywords: plant extracts, fractionation, natural products, antioxidants

RESUMO: Ácido gálico como principal antioxidante da casca do fruto do pequi (Caryocar brasiliense Camb.). Extratos hidroetanólicos da casca do fruto do pequi foram fracionados a fim de identificar e quantificar o principal antioxidante presente. Frações do extrato foram submetidas ao particionamento líquido-líquido e fracionamento em coluna de sílica gel. As atividades antioxidantes das frações foram monitoradas usando ensaio de redução do radical 2,2-difenil-1-picrilhidrazila e a pureza das frações foi avaliada em cromatografia de camada delgada e cromatografia líquida de alta eficiência (CLAE). A substância com propriedades antioxidantes foi identificada através da análise em sistema de cromatografia líquida associada à espectrometria de massas e foi quantificada em HPLC. Após o fracionamento identificou-se uma fração com alta atividade antioxidante e pureza, contendo ácido gálico como o composto principal. Ácido gálico foi encontrado em concentrações de $26,54 \pm 1,13 \mathrm{mg} / \mathrm{g}$ de massa seca. Devido às quantificações terem sido realizadas no extrato hidroetanólico bruto, acredita-se que o ácido gálico esteja presente na forma livre. Assim, a casca do fruto pequi pode servir como interessante alternativa de matéria prima para a produção desse antioxidante natural. Além disso, esse resultado enfatiza o valor da planta do pequi e sugere oportunidades para as famílias que utilizam produtos de pequi.

Palavras-chave: extratos de plantas, fracionamento, produtos naturais, antioxidantes

\section{INTRODUCTION}

Pequi (Caryocar brasiliense Camb. Caryocaraceae) is a native plant that is widely distributed in the Brazilian cerrado (Ratter et al., 2003). It is largely exploited by the native population for its fruits, which are used in cooking, oil extraction, and liqueur production (Chéves-Pozo, 1997). For many families, pequi fruit products are the main source of income during the harvest season, which falls between November and March. Owing to their great economic, social, and ecological importance 
in the cerrado, the pequi plant is protected by law, and several studies have been performed to explore the potential of its products.

The antioxidant potential of the leaf, pulp, and fruit peel extracts of the pequi plant have been described in some recent studies (Khouri et al., 2007; Roesler et al., 2007; Lima, 2008; Porto, 2008; Roesler et al., 2008). Some studies have shown that carotenoid and phenolic compounds are the major antioxidants present in the extracts obtained from the pequi plant (Porto et al., 2008; Roesler et al., 2008). Fruit peel represents the major part of the pequi fruit (approximately 75\%) (Roesler et al., 2007; Rocha, 2011); approximately $200-250 \mathrm{mg} / \mathrm{g}$ of the pequi fruit peel extract dry mass is composed of phenolic compounds (Roesler et al., 2007; Porto, 2008), which represent up to $10 \%$ of the total fruit peel dry mass (Rocha, 2011). Nevertheless, the pequi fruit peel is neglected during fruit processing as a potential feedstock for the production of natural phenolics.

Many studies have shown that phenolic compounds have antioxidant activity (Antolovich et al., 2004; Sousa et al., 2007). They are capable of sequestering free radicals and chelating metals, and are thus involved in the initiation and propagation of oxidative processes (Ramalho \& Jorge, 2006). Besides, clinical and epidemiological studies have shown that natural antioxidants found in vegetables, cereals, and fruits are phenolic in nature and are capable of significantly decreasing the incidence of chronic and degenerative diseases (Roesler et al., 2007; Sousa et al., 2007; Khouri et al., 2007). There is an increasing demand for antioxidants in the pharmaceutical, cosmetic, and food industry (Roesler et al., 2007). Traditionally, synthetic antioxidants have been used for these purposes; however, several studies have shown that these compounds have deleterious effects (Grice, 1986; Wichi, 1988). Thus, the use of natural antioxidants has been encouraged recently (Roesler et al., 2007). Therefore, the aim of our study was to fractionate the pequi fruit peel ethanol-water extract in order to identify and quantify the major antioxidants present in it.

\section{MATERIALS AND METHOD}

\section{Extracts and fractions}

An ethanol:water (4:1) extract was prepared using dried $\left(45^{\circ} \mathrm{C}\right)$ and ground (300-mesh size granules) pequi fruit peels. The extraction was performed at room temperature by mixing $20 \mathrm{~g}$ of ground pequi fruit peels in $200 \mathrm{~mL}$ solvent; $24 \mathrm{~h}$ later, the mixture was filtered to obtain an ethanol-water crude extract. This extract was then fractionated by washing it thrice in hexane; the dried ethanolwater extract was then eluted through a $2.5 \times 20$ cm silica-gel column (Silica Gel 60, 70-230 mesh, $V{ }^{\infty}{ }^{\circledR}$ ) by using increasing polarity gradient mixtures containing ethyl acetate and methanol. Ten fractions of $20 \mathrm{~mL}$ each were collected, and their antioxidant activity was monitored using the 2,2-diphenyl-1picrylhydrazyl (DPPH) radical-scavenging assay.

The purity of the fractions having the highest antioxidant activity was evaluated using thin-layer chromatography (TLC) and high-performance liquid chromatography (HPLC). TLC plates were prepared using Silica Gel 60 GF254 (Vetec ${ }^{\circledR}$ ), and the samples were eluted using an $n$-butanol:water:acetic acid (25:3:2) mixture. The plates were then exposed to iodine vapors in order to obtain a chromatogram. The fractions with the highest purity obtained on the TLC chromatograms were further subjected to chromatography with an HPLC system (Waters ${ }^{\circledR}$ ) equipped with a diode array detector, operating at 190-400 nm. The components of the fractions were resolved by passing them through a $4.6 \times 250 \mathrm{~mm}$ reverse-phase column (RP C18 Microsorb-5 mm) for $15 \mathrm{~min}$ at a flow rate of $0.8 \mathrm{~mL} / \mathrm{min}$. The mobile phase comprised $0.5 \%$ formic acid (solvent $A$ ) and acetonitrile with $0.5 \%$ formic acid (solvent $B$ ). The mobile phase was applied according to the following schedule: $0-2$ min ( $80 \%$ solvent $A$ and $20 \%$ solvent $B), 2-5$ min (reduction in solvent $A$ and increase in solvent $B$ to $100 \%$ ), 5-8 min (maintaining solvent $B$ at $100 \%)$, and $8-15$ min ( $80 \%$ solvent $A$ and $20 \%$ solvent B).

\section{Antioxidant activity}

The antioxidant activity was evaluated using the DPPH radical-scavenging assay (developed by Blois, 1958; adapted by Brand-Williams et al., 1995). The dried fractions were diluted to a $10 \mathrm{mg} /$ $\mathrm{mL}$ solution, and $20 \mu \mathrm{L}$ of this diluted fraction was added to $3 \mathrm{~mL}$ of the $40 \mu \mathrm{g} / \mathrm{mL}$ DPPH-methanol solution. The mixture was shaken vigorously and left to stand in the dark for $30 \mathrm{~min}$. The absorbance was measured at $517 \mathrm{~nm}$ with methanol as a blank. The control was prepared using the plain DPPHmethanol solution. The antioxidant activity (\%) was expressed in terms of the DPPH radical-scavenging capacity of the sample, and was calculated using the following equation, Antioxidant activity (\%) = ([Abs control - Abs sample]/Abs control) $\times 100$, where Abs control = absorbance of the $\mathrm{DPPH}$ methanol solution, and Abs sample = absorbance of the sample (fraction) to be tested (Melo et al., 2006). EC50 ( $\mu \mathrm{g} / \mathrm{mL})$ was calculated from the graph of antioxidant activity percentage against fraction or commercial compound concentration by linear regression analysis. 


\section{LC-MS analysis}

The major antioxidant component in the pequi fruit peel fractions was identified by performing LC-PDA (Orbitrap) mass spectroscopy (MS). HPLC was performed by injecting $10 \mu \mathrm{L}$ of the sample from a cooled tray $\left(6^{\circ} \mathrm{C}\right)$ directly into a Thermo Scientific Phenomenex column that was equilibrated in $95 \%$ solvent $A(0.1 \%$ aqueous formic acid) and $5 \%$ solvent B $(50 \%$ acetonitrile with $0.1 \%$ formic acid). The flow rate was maintained at $200 \mu \mathrm{L} / \mathrm{min}$ at $30^{\circ} \mathrm{C}$, and the gradient was as follows: solvent B, $5-40 \%$ for over 20 min and $40-100 \%$ for over 10 min. A Thermo Scientific LTQ-Orbitrap XL mass spectrometer was operated in the negative-ion mode for full scan analysis (mass range, 80-2000 $\mu$ ), and data-dependent MS/MS was performed using the most intense ions from the full scan at a resolving power of 7,500 ( $0.3 \mathrm{sec} / \mathrm{scan})$. The accuracy of the MS data was confirmed by comparing the elemental composition with the commercially available gallic acid standard (Sigma).

For gallic acid quantification in fruit peel samples, a crude ethanol-water extracts were prepared in triplicates and loaded onto the HPLC system as described above (section 2.1). A commercial gallic acid standard solution was used to construct the calibration curve.

All the analyses were performed in triplicates. The data are expressed as mean and standard deviation (mean \pm SD) values.

\section{RESULTS AND DISCUSSION}

A TLC chromatogram with fractions having the highest antioxidant activity is shown in Figure 1. Other fractions did not show any significant antioxidant activity. Fractions 4 and 5 showed

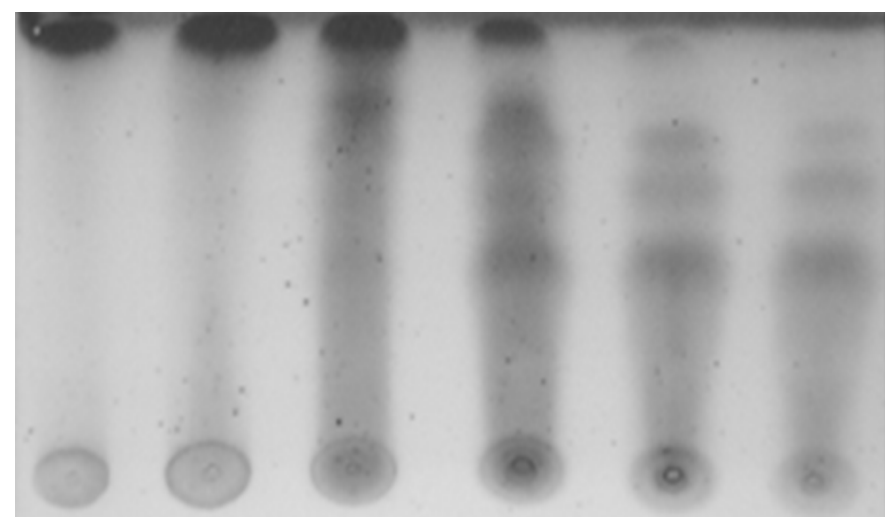

a single band on the TLC chromatogram that matched high antioxidant activities. Therefore, it was suggested that fractions 4 and 5 were of high purity and had an antioxidant substance as its major component. Fractions 4 and 5 were then chromatographed using HPLC to confirm purity and the presence of the antioxidant substance. The HPLC chromatogram (Figure 2) showed a major peak, with lower background noise, for fraction 4 . LC-MS fragmentation analysis showed that gallic acid was the major compound present in fraction 4 (Figure 3).

Roesler et al. (2008) reported that gallic acid is one of the major phenolic compounds present in the pequi fruit peel-ethanol extracts. Other phenolic compounds, such as $p$-hydroxybenzoic acid, quinic acid, quercetin, and quercetin-3-O-arabinose have also been observed but have not yet been quantified. Gallic acid (3,4,5-trihydroxybenzoic acid), a polyphenol present in several fruits, vegetables, and derived products, has been described as a powerful natural antioxidant that is capable of eliminating reactive oxygen species such as superoxide anions, hydrogen peroxide, and hydroxyl radicals (Polewski et al., 2002; Yen et al. 2002). Regarding the use of the gallic acid, several studies have reported the anticancer, anti-angiogenic (Chen et al., 2009; Lu et al., 2010; You \& Park, 2010; Hseu et al., 2011), and antimicrobial properties (Chanwitheesuk et al., 2007;). It is used in the pharmaceutical industry for trimethoprim production and dye manufacturing (Benerjee \& Gargi, 2006). It can also be used to synthesize propyl gallate, a commonly used food antioxidant (Sharma \& Gupta, 2003). Here the antioxidant activity of the purest fraction (fraction 4), was compared to commercial gallic acid and quercetin by the half-maximum effective concentration $\left(\mathrm{EC}_{50}\right)$ values. The $\mathrm{EC}_{50}$ was

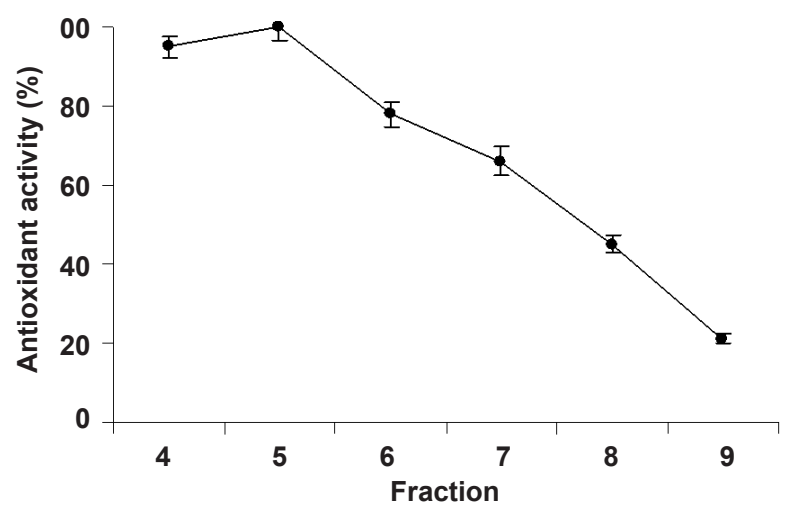

FIGURE 1. Chromatogram obtained after thin-layer chromatography (upper figure) showing the relative antioxidant activity (lower chart) of fractions 4, 5, 6, 7, 8, and 9 of the pequi (Caryocar brasiliense Camb.) fruit peel ethanol-water extract obtained after silica-gel column fractionation. The mobile phase comprised $n$-butanol, water, and acetic acid in the ratio 25:3:2. The TLC chromatogram was resolved by exposure to iodine vapors.

Rev. Bras. PI. Med., Campinas, v.17, n.4, p.592-598, 2015. 

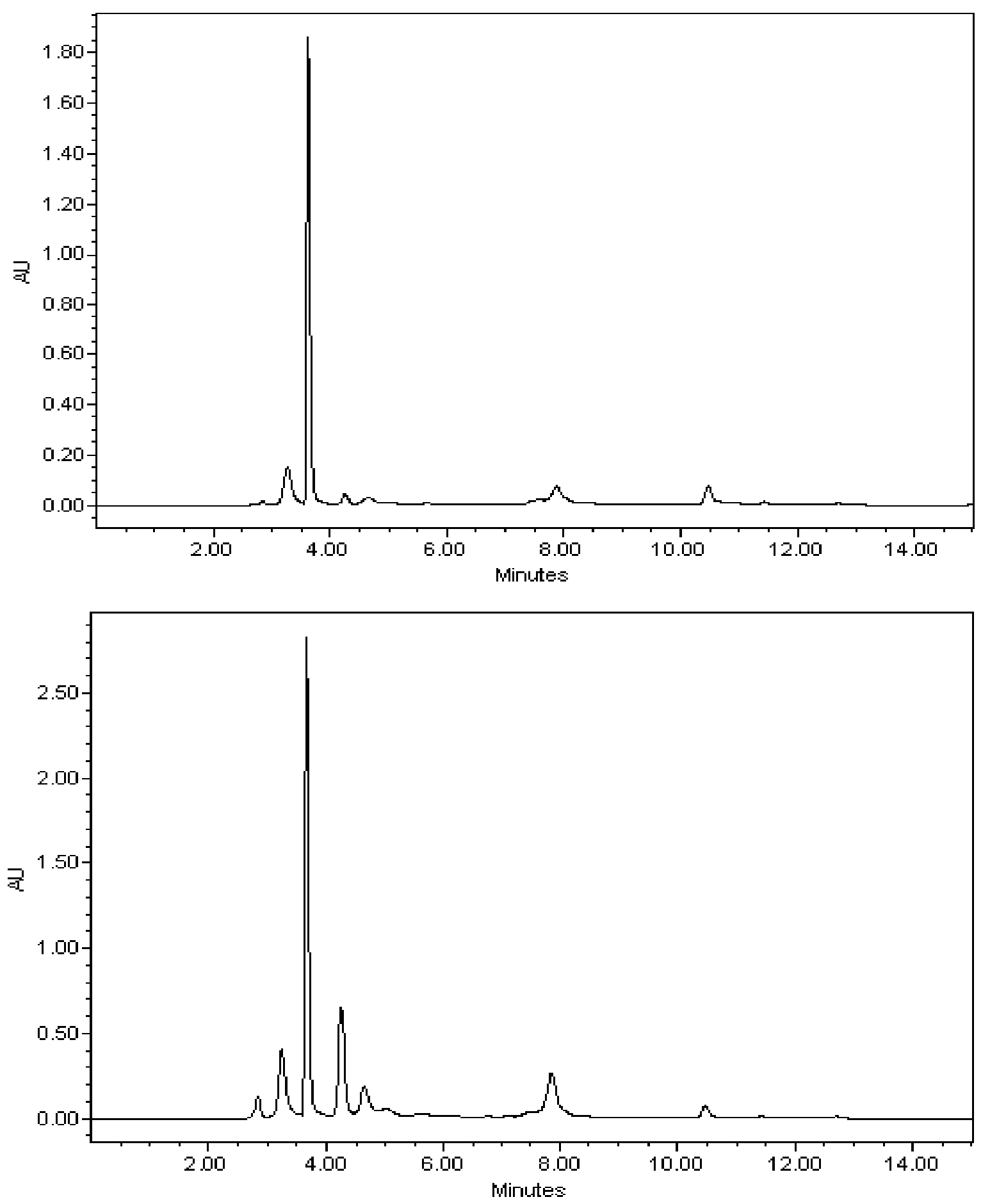

FIGURE 2. High-performance liquid chromatography (HPLC) chromatograms of fractions 4 (upper) and 5 (lower) of the pequi (Caryocar brasiliense Camb.) fruit peel ethanol-water extract obtained after silica-gel column fractionation.

$2,85 \pm 0,14 \mu \mathrm{g} / \mathrm{mL}$ for fraction 4 and $1,60 \pm 0,18 \mu \mathrm{g} / \mathrm{mL}$ and $1,88 \pm 0,26 \mu \mathrm{g} / \mathrm{mL}$, respectively for commercial gallic acid and quercetin. The crude hydro-ethanolic extract was also analyzed and showed value of $18,28 \pm 1,15 \mu \mathrm{g} / \mathrm{mL}$. As can be observed, the rich gallic acid containing fraction 4 from pequi fruit peel showed high antioxidant power, with values near to the tested commercial antioxidants.

Quantitative analysis showed that approximately $26.54 \pm 1.13 \mathrm{mg}$ of gallic acid is present in every gram of the pequi fruit peel dry mass. Because this quantification was performed using the crude ethanol-water extract, which did not receive any additional treatment, it indicated 
geral_2 \#130-147 RT: 2.02-2.28 AV: 3 NL: 1.89E8

T: FTMS - c ESI d Full ms2 243.01@hcd35.00 [100.00-255.00]

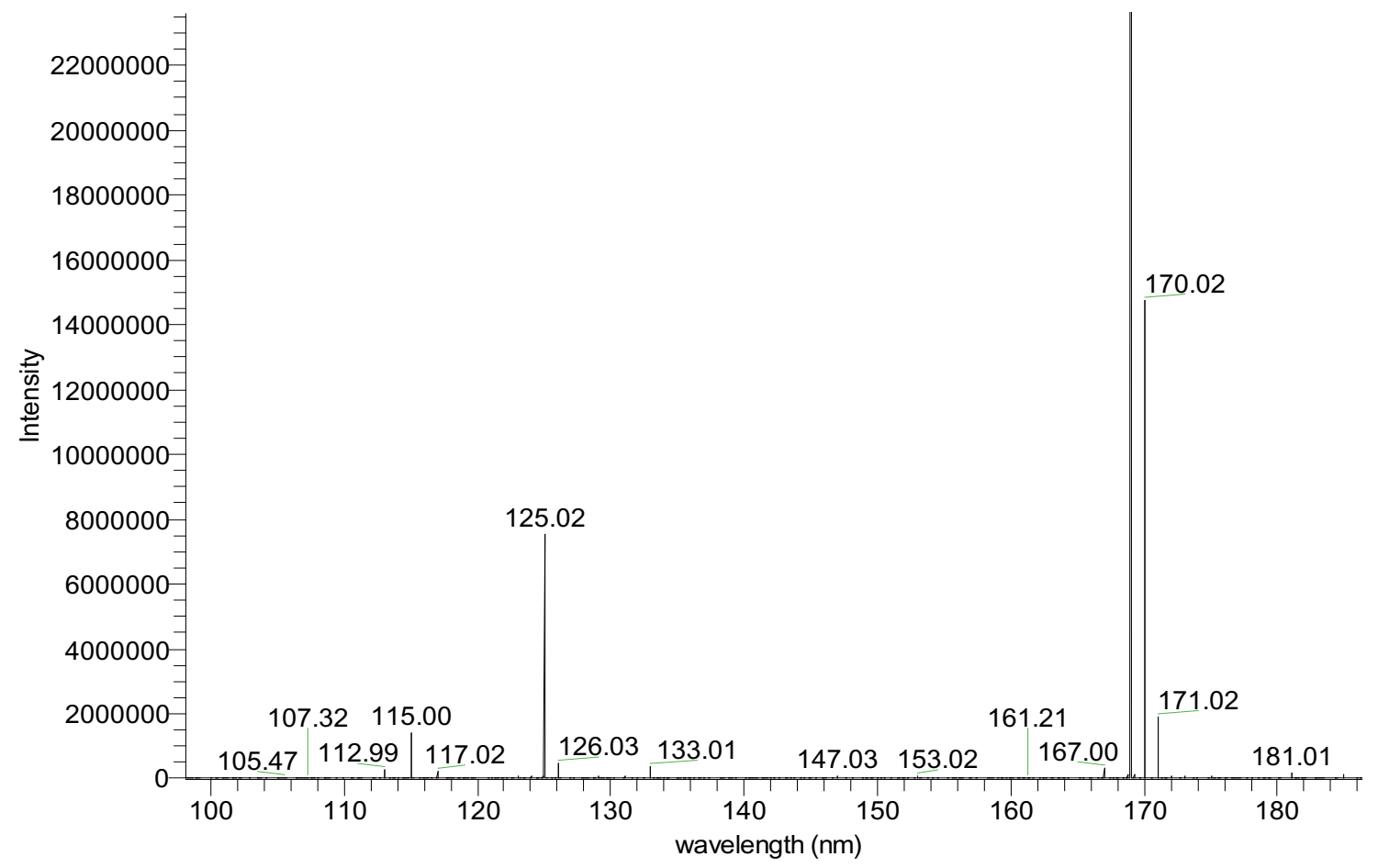

gallic_acid\#138-155 RT: 2.29-2.42 AV: 2 NL: 8.84E7

F: FTMS - p ESIFull ms [80.00-2000.00]

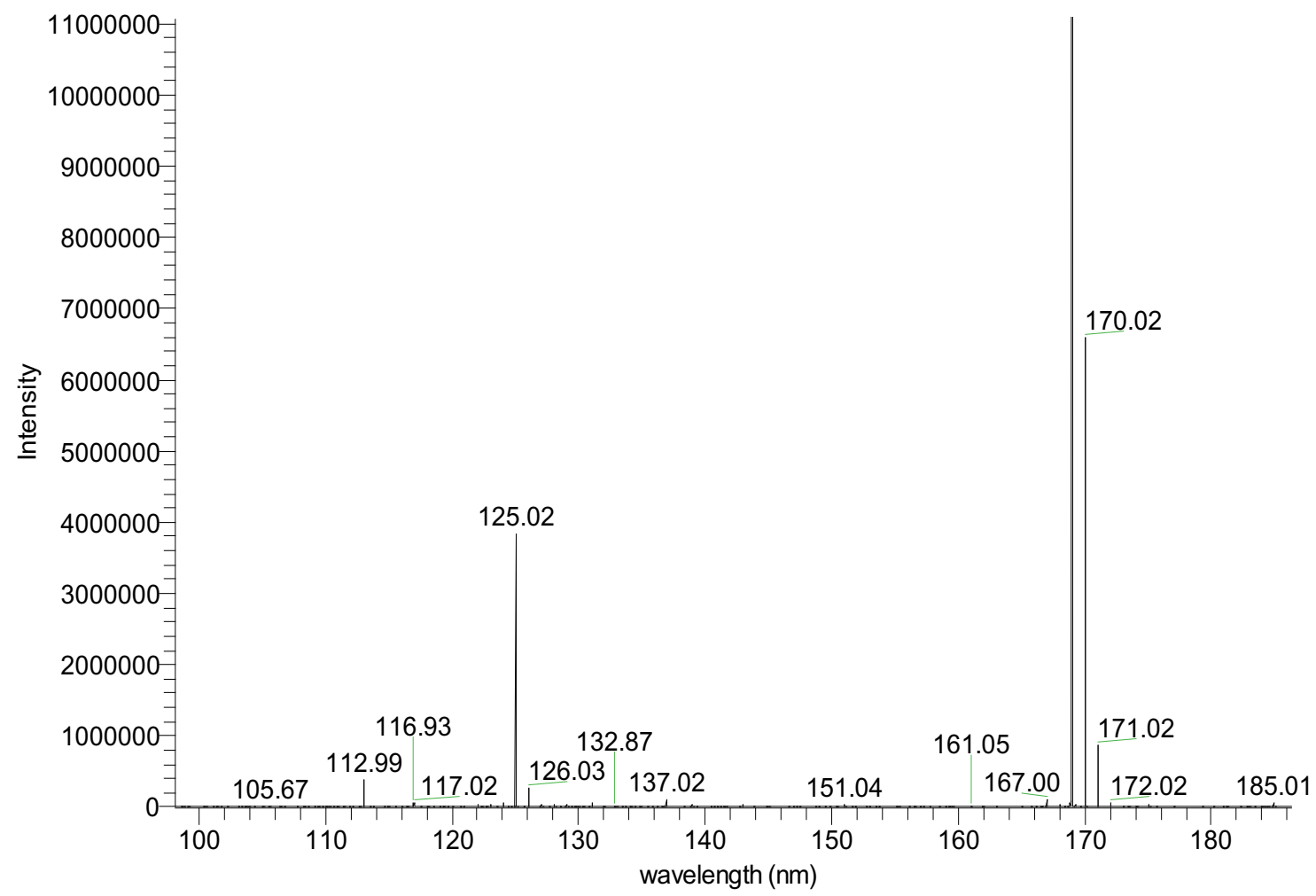

FIGURE 3. Liquid chromatography-mass spectroscopy (LC-MS) fragmentation spectra of the pequi (Caryocar brasiliense Camb.) fruit peel ethanol-water extract fraction (fraction 4) obtained after silica-gel column fractionation (upper) and commercial gallic acid used as the standard (lower).

Rev. Bras. PI. Med., Campinas, v.17, n.4, p.592-598, 2015. 
that gallic acid was present in a free, soluble form in the pequi fruit peels. Low quantities of free gallic acid are generally present in several plants; large-scale production of free gallic acid involves purification from hydrolyzed tannic acid (Yoshida \& Yamada, 1985; Kambourakis et al., 2000). These processes require multiple thermal and/or enzymatic preparation steps, which are costly and may cause severe environmental pollution (Kim et al., 2011). Therefore, using pequi fruit peel as feedstock for production of gallic acid and its derivatives may be a cheaper and environmentally safer alternative. Furthermore, pequi plants are found at densities of about 70 plants/ha in the Brazilian cerrado (Santana \& Naves, 2003; Oliveira, 2009) and have the potential to produce approximately $750 \mathrm{~kg}$ of fruits, and thus, approximately $560 \mathrm{~kg}$ of fresh fruit peel/ ha (Rocha, 2011).

\section{CONCLUSION}

Gallic acid was identified as the major antioxidant of pequi fruit peel where it is present in free soluble form and in considerable concentration. It suggests that pequi fruit peel may serve as an attractive alternative feedstock for natural antioxidant production. Besides, this study emphasizes the value of the pequi plant and suggests improved opportunities for families that use pequi products.

\section{ACKNOWLEDGEMENTS}

This work was supported by Fundação de Amparo à Pesquisa do Estado de Minas Gerais (Fapemig) - Endogornmental demand, process number: DEG-209/09.

\section{REFERENCES}

ANTOLOVICH, M. et al. LC-MS investigation of oxidation products of phenolic antioxidants. Journal of Agricultural and Food Chemistry, v.52, p.962-71, 2004.

BENERJEE, R.; GARGI, M. Process for the preparation of gallic acid by co-culture. U.S. Patent 7,118,822 B2, 2006.

BLOIS, M. Antioxidant determinations by the use of a stable free radical. Nature, v.181, p.1199-200, 1958.

BRAND-WILLIANS, W. et al. Use of a free radical method to evaluate antioxidant activity. LebensmittelWissenschaft und-Technologie, v.28, p.25-30, 1995.

CHANWITHEESUK, A. et al. Antimicrobial gallic acid from Caesalpinia mimosoides Lamk. Food Chemistry, v.100, p.1044-48, 2007.

$\mathrm{CHEN}, \mathrm{H}$. et al. Gallic acid, a major component of Toona sinensis leaf extracts, contains a ROS-mediated anticancer activity in human prostate cancer cells. Cancer Letters, v.286, p.161-71, 2009.
CHÉVEZ-POZO, O.V. O pequi (Caryocar brasiliense): uma alternativa para o desenvolvimento sustentável do cerrado no Norte de Minas Gerais. 1997. 100p Dissertação (Mestrado - Área de concentração em Administração Rural) - Universidade Federal de Lavras, Lavras.

GRICE, H.C. Safety evaluation of butylated hydrotoluene $(\mathrm{BHT})$ in the liver, lung and gastrointestinal tract. Food and Chemical Toxicology, v.24, p.1127-30, 1986.

HSEU, Y. et al. Toona sinensis (leaf extracts) inhibit vascular endothelial growth factor (VEGF)-induced angiogenesis in vascular endothelial cells. Journal of Ethnopharmacology, v.134, p.111-21, 2011.

KAMBOURAKIS, S. et al. Synthesis of gallic acid and pyrogallol from glucose: replacing natural product isolation with microbial catalysis. Journal of the American Chemical Society, v.122, p.9042-43, 2000.

KHOURI, J. et al. Anticlastogenic potential and antioxidant effects af an aqueous extract of pulp from the pequi tree (Caryocar brasiliense Camb.). Genetics and Molecular Biology, v.30, p.442-48, 2007.

$\mathrm{KIM}, \mathrm{T}$.J. et al. Enhanced functional properties of tannic acid after thermal hydrolysis. Food Chemistry, v.126, p.116-20, 2011.

LIMA, A. Caracterização química, avaliação da atividade antioxidante in vitro e in vivo, e identificação dos compostos fenólicos presentes no pequi (Caryocar brasiliense Camb.). 2008. 182p. Tese (Doutorado - Área de concentração em Ciência dos Alimentos). Universidade de São Paulo, São Paulo.

LU, Y.L. et al. Gallic acid suppresses cell viability, proliferation, invasion and angiogenesis in human glioma cells. European Journal of Pharmacology, v.641, p.102-07, 2010.

MELO, E.A. et al. Capacidade antioxidante de oortaliças usualmente consumidas. Ciência e Tecnologia de Alimentos, v.26, p.1-12, 2006.

OLIVEIRA, W.L. Ecologia populacional e extrativismo de frutos de Caryocar brasiliense Camb. no Cerrado no Norte de Minas Gerais. 2009. 82p. Dissertação (Mestrado - Área de concentração em Ecologia) . Universidade de Brasília, Brasilia.

POLEWSKI, K. et al. Gallic acid, a natural antioxidant, in aqueous and micellar environment: spectroscopic studies. Current Topics in Biophysica, v.26, p.217-27, 2002.

PORTO, C.S. Potencial antioxidante de folhas e frutos do pequi (Caryocar brasiliense Camb.). 2008. 32p. Dissertação (Mestrado em Ciências Biológicas). Universidade Estadual de Montes Claros, Montes Claros.

RAMALHO, V.; JORGE, N. Antioxidantes utilizados em óleos, gorduras e alimentos gordurosos. Química Nova , v.29, p.755-60, 2006.

RATTER, J.A. et al. Analysis of the floristic compositionof the Brasilian cerrado vegetation. III: comparison of the woody vagetation of 376 areas. Edinburgh Journal of Botany, v.60, p.57-109, 2003.

ROCHA, L.B. Fracionamento e avaliação das atividades antioxidante, fotoprotetora e citotóxica do extrato hidroetanólico da casca do fruto do pequizeiro (Caryocar brasiliense Camb.). 2011. 36p. Dissertação (Mestrado - Área de concentração

Rev. Bras. PI. Med., Campinas, v.17, n.4, p.592-598, 2015. 
em Ciências Biológicas). Departamento de Biologia Geral, Universidade Estadual de Montes Claros, Montes Claros.

ROESLER, R. et al. Antioxidant activity of Caryocar brasiliense (pequi) and characterization of components by electrospray ionization mass spectrometry. Food Chemistry, v.110, p.711-17, 2008.

ROESLER, R. et al. Atividade antioxidante de frutas do cerrado. Ciência e Tecnologia de Alimentos, v.27, p.53-60, 2007.

SANTANA, J.G.; NAVES, R.V. Caracterização de ambientes de cerrado com alta densidade de pequizeiros (Caryocar brasiliense Camb.) na região sudeste do estado de goiás. Pesquisa Agropecuária Tropical, v.33, p.1-10, 2003.

SHARMA, S.; GUPTA. M.N. Synthesis of antioxidant propyl gallate using tannase from Aspergillus niger van Teighem in nonaqueous media. Bioorganic \& Medicinal Chemistry Letters, v.13, p.395-97,2003.
SOUSA, C.M. et al. Fenóis totais e atividade antioxidante de cinco plantas medicinais. Quimica Nova, v.30, p.351-55, 2007.

WICHI, H.P. Enchanced tumpr development by butylated hydroxyanisole (BHA) from the perspective of effect on forestomach and oesophageal squamous epithelium. Food and Chemical Toxicology, v.26, p.717-23, 1988.

YEN, G. et al. Antioxidant and pro-oxidant properties of ascorbic acid and gallic acid. Food Chemistry, v.79, p.307-13, 2002.

YOSHIDA, H.; YAMADA, H. Microbial production of pyrogallol through decarboxylation of gallic acid. Agricultural and Biological Chemistry, v.49, p.65963, 1985.

YOU, B.R.; PARK, W.H. Gallic acid-induced lung cancer cell death is related to glutathione depletion as well as reactive oxygen species increase. Toxicology in Vitro, v.24, p.1356-62, 2010. 